\title{
Impact of the methane-suppressing feed additive myristic acid on energy and calcium balance of sheep
}

\author{
A. Machmüller ${ }^{1}$ and M. Kreuzer \\ Institute of Animal Science, Animal Nutrition, Swiss Federal Institute of Technology Zurich, \\ ETH Zentrum/LFW \\ CH-8092 Zurich, Switzerland
}

\begin{abstract}
The impact of feeding myristic acid $(\mathrm{C} 14: 0 ; 50 \mathrm{~g} / \mathrm{kg} \mathrm{DM})$ to sheep was investigated in a $6 \times 6$ Latin square arrangement. C14:0 was supplemented to two control diets (forage:concentrate ratios of 1:1.5 and 1:0.5) which were adjusted to different dietary Ca contents (4.2 or $9.0 \mathrm{~g} / \mathrm{kg} \mathrm{DM})$. In combination with the concentrate-based diet, C14:0 reduced methane energy loss by more than 50\% but reduced $\mathrm{Ca}$ availability of the animals while the additional $\mathrm{Ca}$ supply improved $\mathrm{Ca}$ and energy retention. Supplementing C14:0 to the forage-based diet did not affect $\mathrm{Ca}$ availability and resulted in highest feed energy utilization.
\end{abstract}

KEY WORDS: medium-chain fatty acid, methanogenesis, ruminants, metabolizable energy, calcium retention, forage proportion

\section{INTRODUCTION}

The use of fats in ruminant nutrition has gained renewed interest since fat is an important energy source in the diet of high-yielding animals and might be a possible mitigation strategy to reduce the emission of the greenhouse gas methane. In vivo, the methane-suppressing effect especially was demonstrated for fats rich in the mediumchain saturated fatty acids (MCFA), lauric (C12:0) and myristic (C14:0) acid, such as coconut oil (Machmüller and Kreuzer, 1999), and was recently also demonstrated for dietary C14:0 (Machmüller et al., 2003). However, due to interactions among MCFA, fibre and $\mathrm{Ca}$ in the digestive tract the efficiency of $\mathrm{C} 14: 0$ in methane suppression will depend on the dietary proportions of forage and $\mathrm{Ca}$ (Machmüller et al., 2003). Therefore, the objective of the present study was to evaluate whether these interactions with C14:0 also have an impact on energy and Ca balance of ruminants.

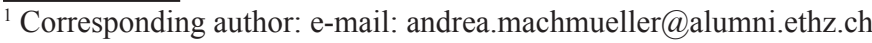




\section{MATERIAL AND METHODS}

The present study was carried out with six castrated male Swiss White Hill breed sheep of $41 \mathrm{~kg}$ body weight in a $6 \times 6$ Latin square arrangement. Two basal diet types of different forage:concentrate ratio (1:1.5 concentrate-based diet type and 1:0.5 forage-based diet type) were fed, calculated to cover 1.3 times maintenance requirements. Both basal diets were supplemented with pure non-esterified C14:0 ( 0 and $50 \mathrm{~g} / \mathrm{kg} \mathrm{DM}$ ) and two levels of dietary Ca (4.2 and $9.0 \mathrm{~g} / \mathrm{kg} \mathrm{DM}$, the latter only in combination with the diets already supplemented with C14:0). The lower level of dietary Ca supply was still within the range recommended for sheep (2.4 to $3.0 \mathrm{~g} \mathrm{Ca} / \mathrm{d}$; ARC, 1980).

In six experimental periods, each sheep received all six dietary treatments but in a different sequence. Experimental periods consisted of $14 \mathrm{~d}$ of adaptation to the respective experimental diet, $8 \mathrm{~d}$ of complete and separate collection of faeces and urine, and $2 \mathrm{~d}$ of quantitative measurement of gaseous exchange in respiratory chambers. On the last day of every experimental period, blood samples were taken from every sheep $5 \mathrm{~h}$ after the morning feeding.

Collection procedure, analyses and calculations were conducted as described by Machmüller and Kreuzer (1999). In feed, faeces and urine, Ca contents were determined photometrically (Naumann and Bassler, 1997). Serum Ca concentration was measured on a COBAS MIRA analyser (Roche Diagnostics, Basle, Switzerland) using a commercial test kit (Roche Diagnostics) and serum calcitriol (1,25-dihydroxyvitamin $\mathrm{D}_{3}$ ) concentration by using a gamma counter (GAMMAmatic 1, Kontron Instruments, Zurich, Switzerland) and a commercial radioimmunoassay kit (Nichols Institute Diagnostic, San Clemente, CA, USA).

\section{RESULTS AND DISCUSSION}

Supplementing the basal diets with $50 \mathrm{~g} / \mathrm{kg}$ DM of C14:0 increased daily intakes of gross energy (Table 1), digestible energy and metabolizable energy (ME; data not shown) by 8,5 and $12 \%$ on average, respectively. C14:0 supplementation reduced gross energy loss via methane and urine. However, the improvement in energy retention (RE) by on average $34 \%$ was not significant, because gross energy loss via faeces numerically increased.

The calculated ME value of $\mathrm{C} 14: 0$ was $24.5 \mathrm{MJ} / \mathrm{kg}$ when added to the concentrate-based diet type and $32.1 \mathrm{MJ} / \mathrm{kg}$ when added to the forage-based diet type. The present data highlight that there is no single value for the ME content of fat as it will be specifically determined by the composition of the basal diet used. Thus increasing the dietary Ca content resulted in an improvement in the calculated ME value for added C14:0 in the concentrate-based diet to $32.6 \mathrm{MJ} \mathrm{ME} / \mathrm{kg}$ which is similar to the $33.3 \mathrm{MJ} \mathrm{ME} / \mathrm{kg} \mathrm{C} 14: 0$ found for the Ca-supplemented forage- 
based diet. Compared to the forage-based diet type, lower RE:ME ratios (data not shown) were found with the concentrate-based diet type, which further gives evidence that the effect of added C14:0 on the nutrient digestion of the basal diet and, along with that, on the energy utilization of the complete diet is depending on the basal diet type, specifically on its fibre and $\mathrm{Ca}$ content.

Table 1. Effect of C14:0 supplementation on gross energy (GE) intake and energy balance ( $\mathrm{n}=6)$

\begin{tabular}{|c|c|c|c|c|c|c|}
\hline \multirow{3}{*}{$\begin{array}{l}\mathrm{C} 14: 0, \mathrm{~g} / \mathrm{kg} \mathrm{DM} \\
\mathrm{Ca}, \mathrm{g} / \mathrm{kg} \mathrm{DM}\end{array}$} & \multicolumn{3}{|c|}{ Concentrate-based diet type } & \multicolumn{3}{|c|}{ Forage-based diet type } \\
\hline & 0 & 50 & 50 & 0 & 50 & 50 \\
\hline & 4.2 & 4.2 & 9.0 & 4.2 & 4.2 & 9.0 \\
\hline GE intake, $\mathrm{MJ} / \mathrm{d}$ & 13.43 & 14.10 & 14.94 & 15.68 & 17.22 & 17.43 \\
\hline \multicolumn{7}{|c|}{ Energy balance, \% of GE intake } \\
\hline \multicolumn{7}{|c|}{ Energy loss } \\
\hline faeces & 31.2 & 33.7 & 34.0 & 33.7 & 34.3 & 34.1 \\
\hline urine & $3.9^{\mathrm{a}}$ & $3.2^{\mathrm{ab}}$ & $3.4^{\mathrm{ab}}$ & $3.8^{\mathrm{a}}$ & $2.7^{\mathrm{b}}$ & $2.9^{\mathrm{b}}$ \\
\hline methane & $7.4^{\mathrm{a}}$ & $2.9^{c}$ & $3.5^{\mathrm{c}}$ & $6.4^{\mathrm{a}}$ & $4.5^{\mathrm{b}}$ & $4.9^{b}$ \\
\hline $\mathrm{EE}^{1}$ & $50.4^{\mathrm{a}}$ & $52.6^{\mathrm{a}}$ & $49.4^{\mathrm{ab}}$ & $46.0^{\mathrm{bc}}$ & $43.1^{\mathrm{c}}$ & $42.7^{\mathrm{c}}$ \\
\hline Energy retention & 7.1 & 7.6 & 9.7 & 10.1 & 15.4 & 15.4 \\
\hline
\end{tabular}

${ }^{1}$ EE: energy expenditure (heat production)

${ }^{a, b, c}$ mean values with different lower case letters in the same row are significantly different

With regard to $\mathrm{Ca}$ balance, it is assumed that, due to formation of insoluble complexes between $\mathrm{C} 14: 0$ and $\mathrm{Ca}$ ions in the rumen and in the large intestine, the addition of $\mathrm{C} 14: 0$ resulted in a negative Ca retention in the concentrate-based diet, while there was no effect in the forage-based diet (Table 2). Increasing the $\mathrm{Ca}$ level of the diets from 4.2 to $9.0 \mathrm{~g} / \mathrm{kg} \mathrm{DM}$ increased the daily amount of $\mathrm{Ca}$ ingested, excreted via faeces, digested and retained on average to 2.2-, 1.9-, 4.0- and 4.7-fold values, respectively, but did not change the daily urinary $\mathrm{Ca}$ excretion (data not shown). With the concentrate-based diet type, the extra $\mathrm{Ca}$ resulted in a return to a positive Ca balance. Animals retained on average $1.0 \mathrm{~g}$ $\mathrm{Ca} / \mathrm{d}$, which was similar to that found in the diet not supplemented with C14:0. By contrast, serum $\mathrm{Ca}$ (data not shown) did not clearly respond to the changes in $\mathrm{Ca}$ retention and ranged around $2.4 \mathrm{mmol} / \mathrm{L}$. Apparently, the metabolic $\mathrm{Ca}$ supply was always sufficient for homeostatic control. However, the need for extra $\mathrm{Ca}$ with the C14:0-supplemented concentrate-based diet was clearly visible from a response in the serum calcitriol level (data not shown). With this basal diet type, the addition of C14:0 significantly increased the mean serum calcitriol level from 53 to $82 \mathrm{pg} / \mathrm{ml}$, an effect not occurring when simultaneously extra Ca was given. 
Table 2. Effect of C14:0 supplementation on Ca intake and Ca balance $(\mathrm{n}=6)$

\begin{tabular}{|c|c|c|c|c|c|c|}
\hline \multirow{3}{*}{$\begin{array}{l}\mathrm{C} 14: 0, \mathrm{~g} / \mathrm{kg} \mathrm{DM} \\
\mathrm{Ca}, \mathrm{g} / \mathrm{kg} \mathrm{DM}\end{array}$} & \multicolumn{3}{|c|}{ Concentrate-based diet type } & \multicolumn{3}{|c|}{ Forage-based diet type } \\
\hline & 0 & 50 & 50 & 0 & 50 & 50 \\
\hline & 4.2 & 4.2 & 9.0 & 4.2 & 4.2 & 9.0 \\
\hline Ca intake, g/d & 3.18 & 3.05 & 6.74 & 3.74 & 3.74 & 7.87 \\
\hline \multicolumn{7}{|c|}{ Ca balance, \% of Ca intake } \\
\hline \multicolumn{7}{|c|}{$\mathrm{Ca}$ loss } \\
\hline faeces & $69.4^{\mathrm{b}}$ & $104.7^{\mathrm{a}}$ & $84.4^{\mathrm{ab}}$ & $83.7^{\mathrm{ab}}$ & $78.2^{\mathrm{ab}}$ & $74.9^{\mathrm{ab}}$ \\
\hline urine & 2.3 & 2.2 & 0.6 & 2.3 & 1.8 & 1.1 \\
\hline Ca retention & $28.3^{\mathrm{a}}$ & $-6.9^{b}$ & $15.0^{\mathrm{ab}}$ & $14.0^{\mathrm{ab}}$ & $20.0^{\mathrm{ab}}$ & $24.0^{\mathrm{ab}}$ \\
\hline
\end{tabular}

${ }_{\mathrm{a}, \mathrm{b}}$ mean values with different lower case letters in the same row are significantly different

\section{CONCLUSIONS}

The present study gives evidence, that specific dietary measures have to be applied when using diets enriched in medium-chain fatty acid (MCFA) for methane-suppressing and energetic purpose. A high methane-suppressing activity of MCFA can be achieved with diets where rumen interaction of MCFA with dietary compounds remains as low as possible. In turn, high dietary fibre and $\mathrm{Ca}$ contents partially inactivate the methane-suppressing MCFA. However, with regard to the $\mathrm{Ca}$ availability for the animal the present data show that the recommended $\mathrm{Ca}$ content of C14:0-supplemented concentrate-based diet types has to be increased. On the other hand, having the aim to maximize energy retention with MCFA-supplemented diets needs the use of feeding regimes less efficient in methane abatement, i.e. forage-dominated, Ca-supplemented diets.

\section{REFERENCES}

ARC, 1980. The Nutrient Requirements of Ruminant Livestock. Commonwealth Agricultural Bureaux, Slough

Machmüller A., Kreuzer M., 1999. Methane suppression by coconut oil and associated effects on nutrient and energy balance in sheep. Can. J. Anim. Sci. 79, 65-72

Machmüller A., Soliva C.R., Kreuzer M., 2003. Methane-suppressing effect of myristic acid in sheep as affected by dietary calcium and forage proportion. Brit. J. Nutr. 90, 529-540

Naumann K., Bassler R., 1997. Methodenbuch. Band III. Die chemische Untersuchung von Futtermitteln. 4th Edition. VDLUFA-Verlag, Darmstadt 